Cytogenet Genome Res 1977;18:1

\title{
Special Notice to Contributors and Subscribers
}

We are pleased to announce the following changes in the structure and composition of the Editorial Board of this Journal and in some of the manuscript review procedures.

Full or brief reports may now be sent either to the Editor-in-Chief or directly to one of the Associate Editors providing that the theme of the paper falls within the investigative section listed on the inside of the cover for that Associate Editor. Manuscripts will continue to be reviewed by at least two referees, one of which may be the Associate Editor.

Please consult the "Instructions to Authors" section for further details.

Cytogenet Genome Res and Cell Genetics will continue to publish two volumes annually, each composed of six issues. The Brief Reports section, initiated recently, will be continued - as will publication of descriptions of cell lines maintained by the Human Genetic Mutant Cell Repository, Camden, N.J., which is sponsored by the National Institutes of Health, USPHS. The publication costs of these descriptions are borne by the Repository and thus do not influence subscription rates.

In collaboration with The National Foundation-March of Dimes, this Journal will continue publication of the International Workshops on Human Gene Mapping. The fourth workshop will be held August 14-18, 1977 in Winnipeg, Canada (Dr. J.L. Hamerton, host). 